\title{
Leaders: a comparative analysis of the various leadership styles
}

\author{
Líderes: uma análise comparativa dos vários estillos de liderança \\ Líderes: un análisis comparativo de los distintos estilos de liderazgo
}

Received: 11/06/2021 | Reviewed: 11/11/2021 | Accept: 11/15/2021| Published: 11/24/2021

\author{
Maria Edwige dos Santos Pires \\ ORCID: https://orcid.org.0000-0002-1604-6439 \\ Faculdade de Negócios Excellence, Brazil \\ E-mail: edwige.pires@alcoa.com \\ Sandra Maria dos Santos \\ ORCID: https://orcid.org.0000-0002-8515-9146 \\ Universidade Federal do Ceará, Brazil \\ E-mail: smsantosufc@gmail.com \\ Genivaldo Marcilio Frez \\ ORCID: https://orcid.org/0000-0001-5943-9235 \\ Instituto Universitário Eseade, Brazil \\ E-mail: genivaldoeseade@gmial.com \\ Marcelo Rabelo Henrique \\ ORCID: https://orcid.org/0000-0002-5940-4267 \\ Universidade Federal de São Paulo, Brazil \\ E-mail: marcelo@mrhenriqueconsult.com.br
}

\begin{abstract}
It is known that organizations within an evolutionary perspective are in constant learning (learning organizations), so they equip of the ability to learn how to properly respond to the particularities of demands, for this reason organizations understand the need to measure its performance. In this segment of learning and adapting to the demand, the image of the leader and leadership styles become one of the main pillars of strategic management. Therefore, the guiding question of this article lies in a comparative analysis of different leadership styles mainly proposed by three authors: Blanchard and Hersey; Warren Bennis (2001) and Jack Welch; and Max Weber (2016). Other authors have also contributed which came to enrich the epistemological matrix of this research. Thus this research was categorized as basic, analytical, qualitative, of exploratory and descriptive nature due to the observation of facts, analysis and interpretation. Information on the bibliography was classified considering its interpretive epistemological approach. Data were capitulated through reflective reading of theme in focus. One has to conclude that operational compliance process does not counterbalance ineffective people; however, operational compliance process does not block effective people. In this antagonism, the employee ceases to be "simply a piece of Taylor," and goes on to add value, once they have the authority over entire system. The combination between effective leaders and operational compliance process is value-adding for the maintenance and growth of organizations.
\end{abstract}

Keywords: Leader; Leadership; Organization.

\section{Resumo}

Sabe-se que as organizações dentro de uma perspectiva evolutiva estão em constante aprendizado (organizações que aprendem), por isso se dotam da capacidade de aprender a responder adequadamente às particularidades das demandas, por isso as organizações entendem a necessidade de mensurar seu desempenho. Nesse segmento de aprendizado e adaptação à demanda, a imagem do líder e os estilos de liderança passam a ser um dos principais pilares da gestão estratégica. Portanto, a questão norteadora deste artigo reside em uma análise comparativa de diferentes estilos de liderança propostos principalmente por três autores: Blanchard e Hersey; Warren Bennis (2001) e Jack Welch; e Max Weber (2016). Outros autores também contribuíram, o que veio enriquecer a matriz epistemológica desta pesquisa. Assim esta pesquisa foi categorizada em básica, analítica, qualitativa, de natureza exploratória e descritiva devido à observação dos fatos, análise e interpretação. As informações da bibliografia foram classificadas considerando sua abordagem epistemológica interpretativa. Os dados foram capitulados por meio da leitura reflexiva do tema em foco. É preciso concluir que o processo de conformidade operacional não contrabalança pessoas ineficazes; no entanto, o processo de conformidade operacional não bloqueia pessoas eficazes. Nesse antagonismo, o funcionário deixa de ser "apenas um pedaço de Taylor" e passa a agregar valor, uma vez que detém autoridade sobre todo o sistema. A combinação entre líderes eficazes e processo de conformidade operacional agrega valor para a manutenção e o crescimento das organizações.

Palavras-chave: Líder; Liderança; Organização. 


\section{Resumen}

Se sabe que las organizaciones dentro de una perspectiva evolutiva están en constante aprendizaje (organizaciones de aprendizaje), por lo que se dotan de la capacidad de aprender a responder adecuadamente a las particularidades de las demandas, por ello las organizaciones entienden la necesidad de medir su desempeño. En este segmento de aprendizaje y adaptación a la demanda, la imagen del líder y los estilos de liderazgo se convierten en uno de los principales pilares de la gestión estratégica. Por tanto, la pregunta orientadora de este artículo radica en un análisis comparativo de diferentes estilos de liderazgo propuestos principalmente por tres autores: Blanchard y Hersey; Warren Bennis (2001) y Jack Welch; y Max Weber (2016). También han contribuido otros autores que llegaron a enriquecer la matriz epistemológica de esta investigación. Así, esta investigación fue categorizada como básica, analítica, cualitativa, de carácter exploratorio y descriptivo debido a la observación de hechos, análisis e interpretación. La información de la bibliografía se clasificó considerando su enfoque epistemológico interpretativo. Los datos se capitularon a través de una lectura reflexiva del tema en foco. Hay que concluir que el proceso de cumplimiento operativo no contrarresta a las personas ineficaces; sin embargo, el proceso de cumplimiento operativo no bloquea a las personas eficaces. En este antagonismo, el empleado deja de ser "simplemente una pieza de Taylor" y continúa agregando valor, una vez que tiene la autoridad sobre todo el sistema. La combinación entre líderes efectivos y proceso de cumplimiento operativo es un valor agregado para el mantenimiento y crecimiento de las organizaciones.

Palabras clave: Líder; Liderazgo; Organización.

\section{Introduction}

A particularity associated to organizations is the search for competitive maintenance prices, delivery time, return of capital, quality and image. In this sense, organizations are challenged to leave the endogenous and enter the strategic, in a global exposure to recognize the personal value has become an important business continuity tool in the last decades.

Thus, it is evident the respectable role of the leaders in this context, who, given the evolution and the emergence of theories that guide the professional leadership styles, appear as articulators of the business vision and the conductors of the organization.

So, the purpose of this study is to establish a comparative analysis of different leadership styles, highlighting four main authors. In terms of structure, besides this introduction, the work has six (6) sections configured as followed: from sections 2 to 4 the discussion is the theoretical referential; sections 5 and 6 deal with the methodology and data analysis respectively, followed by a conclusion.

\section{Etymology}

The etymology of the word "lead" is of English origin and means, among other things, to conduct, direct, guide, head, carry. According to Mueller and Mayer (2003), the settlement of this word is connected with the word ducere, derived from the Latin, which influenced the derivation of the verb to lead, which in turn gave sequence to the term leading, which is translated by "action of conducting ". Later, in accordance with Mirador (1987), comes the word Leadership, meaning "function of guiding, conductor or boss"

According to Marquis and Houston (1999), the word "leader" dates back to the fourteenth century, suggesting that who leads, since the word "leadership" is found in English only in the early nineteenth century

Leaders, to lead, leadership are terms in vogue in the organizational environment.

\section{Leaders and Leadership Contextualization}

The great leaders of mankind such as Moses, who led his people to Canaan; Mahatma Gandhi, who was a defender of the principle of non-aggression as a means of revolution; Adolf Hitler, Nazi leader responsible for the Holocaust; Martin Luther King, a member of the Baptist Church, leader of the civil rights activism; Margaret Thatcher, adept of Friedrich 
Hayek's economic ideology, was considered the most energetic leader of the British Conservative Party, all congregated their groups and formed coalitions towards one goal.

Leaders, as the ones mentioned above, have different characteristics from each other. Some are pacifists, other activists, some conservative, some liberal, some make revolutions using words others using guns, some with a divine commission other against it, but all have something in common: the ability to involve hundreds of people and to lead their followers.

Every leader has their distinct way of guiding their followers to the desired objective, and the delegation of activities or authority is shared with them, sometimes in a very explicitly way. Freedom and empowerment, on the other hand, are not easy to transmit or share. The study by Conley \&You (2018) points out that the leader who shares his management, involving his team in business decisions, improves the organizational climate and still retains employees in the organization to the extent of empowerment. There are leaders, for instance, who have a persuasion power that can make people believe that they are not always in a supportive role; there are leaders who do not let people fall over ostracism, leaders with attitude, who make their colleagues and subordinates understand, accept and respect the company policy.

As noted previously, the words leading, lead, leadership, are now common vocabulary in organizations. This scenario occurs because of the importance leaders have in the company, as they corroborate with the organization to achieve its goals and fulfil its mission. They are also responsible for the new architecture of human resources, in which appreciation for people and stimulus to overcome challenges to achieve the results are characteristic sine qua non in the competitive world. The leader's role in the organizational context permeates the understanding of employee retention and attraction factors.

Leadership, says Robbins, Judge and Sobral (2010), is the ability to influence a group towards goal attainment. Peter Senge (2009) addresses the collective aspect of leadership emphasizing that leaders conduct changes, and that that is expected from true leaders. The leaders' role is to be a projector, supervisor and conductor. Vergara (2014) mentions that leadership is the ability to influence individuals and groups. Kotter (quoted Ronchi 1997, p.96) explains that "leading by example has a simple concept: words can be forgotten, but actions cannot".

There are many definitions about the importance of the Leader. To Rhinesmith (2003) this individual must be provided with sensitivity and assessment ability, caution when critically analyzing different situations, capacity of being flexible when needed, being fit for new learning and breaking paradigms and, above all, have knowledge and information about the business of their organization.

Therefore, the leader must be able to explore new possibilities for a particular purpose. That said, organizations presently invest in training and retention of such power (skill / knowledge / attitude). Nevertheless, there is an evident challenge for organizations: the development of leaders and employees with the ability to commit to the organization's results and operationalize management tasks. Rhinesmith (2003) notes that leadership demands humbleness from the leader to be susceptible to continuous learning, so that those leaders can mobilize people and or groups to opt for a particular company decision.

In this context of mobilization and leadership, the future is mixed up with the present. Johannpeter, (2008, p.139) states that "the leader of the future adds to their expertise a strong capacity to mobilize people through actions. In addition, the simplicity and passion in how the leader carries out their tasks are key, as these ensure assertiveness, focus and ability to listen to the team." Now, Rhinesmith (2003) mentions that the current leader holds behavioral and technical skills, knows how to deal with inaccurate situations, is ethical and absorbs the organization's values.

Leaders are not necessarily managers, They can be an operator, an analyst, a cultured employee, or someone who, even without much culture, will play the role of a leader from the moment they perform their task with excellence and simplicity, while having the ability to listen to their colleagues and superiors, approach others and showing them that they are 
important, as well as being able to transform lamentations and complaints into understanding the organization's guiding values and policies. They must not be seen as a boss. Bosses are people occupying positions delegated by the organization; the leader does not need the organization's delegation to be a leader, they are naturally a leader, although there are leaders with a delegation position acting as leaders-managers.

Some theories claim that leadership is born with the individual and can be perfected throughout one's life. From this perspective, Bennis (1996) authenticates this thought by stating that leadership is not taught since the foundation of leadership is character and judgment, values that that one can refine but not teach. However, for Vergara (1999), there is no grounding for this argument, as for her leadership is not innate. An individual is not born leader, but learns how to be one. Peter Drucker (2003) also argues that leadership can be taught, therefore it can be learned.

This dialectic, however, is irrelevant to establish positions in the organizational hierarchy, therefore, whether or not the individual is born with the profile of leadership or the ability to learn to be a leader from their first manifestations of will, it is evident that they cannot always be part of the organization's top management. As leaders are opinion-makers, but often are not part of the organization's top management and having the organization the challenge of being entrepreneurial to be competitive, attracting and retaining these resources, both from within and outside the organization, is an important factor for the company's business strategy.

Still in this segment, Vergara (2014) announces "in this new era what you want are people with a global mindset, accepting and dealing with life's contradictions and the unexpected, opening up both for themselves and for others, finding meaning in work and allowing others to also find it " (p.29). Chowdhury (2020) claims that it is necessary for organizations to seek and prepare visionary people (leaders), who are innovators capable of adapting to the new reality while remaining competitive. Therefore, such people should hold certain characteristics that enable them to facilitate the influence process.

An individual, especially inside an organization, can be simply influenced, and not necessarily by their superior, to do certain activities or they may do so through coercion. It is in this light that rests the theory of Max Weber (2016) - Power and Authority. Through power the governed are forced and coerced to perform their duties, this is the ability of an individual to obey an order by force; through authority, the activities are performed voluntarily, the governed legitimately see the role and the position of their superior, being this the ability to make an individual obey voluntarily. In this sense, Max Weber (2016) defines types of authority, namely: Traditional, Charismatic and Legal Rational. Table 1 below shows the types of authority proposed by Weber (2016).

Table 1: Authority Types.

\begin{tabular}{|l|l|l|}
\hline \multicolumn{1}{|c|}{ Traditional } & \multicolumn{1}{c|}{ Charismatic } & \multicolumn{1}{c|}{ Rational Legal } \\
\hline Delegated authority & Charismatic authority & Bureaucratic authority \\
\hline Legitimate performance & Arising from leadership, led & $\begin{array}{l}\text { Legality in the fundamentals of } \\
\text { laws }\end{array}$ \\
\hline $\begin{array}{l}\text { Exercised by a person or by } \\
\text { delegation who has the power } \\
\text { to command }\end{array}$ & $\begin{array}{l}\text { Has dexterity to involve peers, } \\
\text { subordinates and even superiors } \\
\text { to do what is expected free } \\
\text { willingly }\end{array}$ & $\begin{array}{l}\text { Arising from post, function or } \\
\text { position defined by a hierarchy }\end{array}$ \\
\hline & $\begin{array}{l}\text { Convince others to believe in the } \\
\text { individual and collective benefit }\end{array}$ & \\
\hline
\end{tabular}

Source: Prepared by the authors from Weber (2016). 
For organizations, Legal Rational authority is one of the most important, because if the common sense sees bureaucracy as a synonymous for complication, this view was not shared by Weber (2016). For him, bureaucracy was required because it is organized, efficient and standardized, whoserules must be clear and the procedures concise.

One of Max Weber's (2016) concerns was to make association between formal authority and leadership. It should be taken into account that, dialectically, segregation between power and authority occurred and, in sequence, the stratification of Formal Authority with Leadership. Formal authority takes on standards, belongs to the position and not to the individual and is permanent as long as the position exists, so it can be ephemeral. In contrast is the leadership which is based on natural acceptance and is limited to the social group within which the leader exerts influence. Similar to formal authority, leadership is also ephemeral, but it persists only while the harmony between leader and led persists.

Max Weber (2016) mentions that organizations are built, manufactured and constantly rebuilt, that conflicts between people (motivated or not) exist, but will be phased out by internal and external reasons. His concerning was related to questions of what organizations do to perpetuate the environments in which they operate and what would keep them functioning. These organizations are composed of positions and employees functionally distributed according to the company structure whose rules are imposed clear and written form.

Following the Weberian approach, the first studies on leaders' behaviour arose. It is the analysis of management styles, defined as follows: autocratic (authoritarian, directive, impersonal); democratic (participatory consensus); and laissezfaire (in which the leader give up their leadership role and transfers it to the group).

In today's organizational structure, due to the global market, the tendency is to not work with power, but with the authority associated with the leading image. In this sense, according to Resende (2004), the leadership can be seen as a function of control or a quality that allows an individual to influence or lead people towards an objective. Thus, it is clear that leadership is the exercise of authority.

\section{Leadership Styles}

There are theories defending the perspective that people are not born leaders, but are developed, shaped and improved, it is the case, previously mentioned, of Vergara, however there are authors who believe that leadership is a divine gift, and that true leaders are predestined to such mission. Moscovici (2006) approaches the concept of divine leadership, citing the mythical figure of Moses "A man then receives a divine commission to free the people from slavery. This is the leader in the original sense of the word, he who guides the others safely to their destination" (p.71). With very close to this conception, expressed Shiyashiki cited in Resende (2008), "one of the main features of a born leader's own ability is to serve their subordinates and always be able to hear and assist in the search of goals."

The best scenario for some organizations is to identify people who are leaders, opinion makers and have charisma, however Resende (2008, p.18) states that "according to some experts, if the company wants a good leader, they should seek character instead of charisma." One has to emphasize that the charismatic figure is for the Weberian theory one of the three ideal types of authority, as highlighted in the previous section.

In Weber's (2016) theory, the charismatic leader is someone gifted with powers as well as supernatural and superhuman qualities. This statement contradicts the Vergara's thesis that acknowledges the theory in which the individual is not born leader, but learns to be one.

Through the commitment and challenge organizations face, i.e. making a profit, maximizing performance, minimizing costs, competitiveness, satisfaction and staff morale, these approaches do not add to the organization results, in real terms what matters is the image of the leader and the return of capital they bring to the company, so companies often, through their 
managers or organizational consultants, seek to identify and absorb in the market, or even within the organization itself, individuals with traces of leaders who are susceptible to relate to the values and mission of the company.

For some organizations, the fundamental importance in identifying and developing leaders is strategic rather than operational and is embraced by the competitiveness and restructuring of human resources towards training and talent retention. Werneck (2020) highlights the pressing need for organizations to strategically restructure, list and train their team members to meet the new organizational scenario arising from uncontrollable variables such as the Coronavirus pandemic. For this author, this is a work to be managed by the leader, who must also be a people manager. Otherwise, the retention of talents is committed.

Within this context, Ronchi (2007) indicates that the favorable results arising from being a leader in an organization are due to a learning structure as a way to establish or maintain competitive advantage. Therefore, it is an ongoing, uninterrupted process, regardless of being coated in formality or informality. This learning requires the knowledge on different leadership theories, as the leadership style identified by Blanchard and Hersey (Situational Theory); Warren Bennis (1996) (key elements) and the leadership style developed by Jack Welch (The 4-Es of Leadership).

In order to facilitate the contextualization of each style with their thinkers, each of these authors will be assigned an association of terminology.

\subsection{Situational Leadership Theory - The Four Styles}

Hersey, Blanchard, and Johnson 2013, creators of the situational leadership theory, which was originally known in the 70 s as the life cycle of leadership theory, identified four leadership styles applied to different situations present in the daily life of a leader

The situational leadership theory draws upon circumstantial variables in which the individual is compelled to administer, which are: command; sale participation, and delegation. (Hersey, Blanchard, and Johnson 2013).

For this theory, the important aspect of the leadership is the adaptability and amplitude of style. It is understood for adaptability the ability to vary the leadership style according to the situation faced by the leader and/or organization. The table 2 below describes the characteristics associated with each situation.

Table_2: Situational Styles.

\begin{tabular}{|c|c|c|c|}
\hline Telling & Selling & Participating & Delegating \\
\hline Autocratic style & Coaching style & Facilitator style & Trust style \\
\hline $\begin{array}{l}\text { Employees are not prepared } \\
\text { to carry out an activity }\end{array}$ & $\begin{array}{l}\text { Guide subordinates, peers to } \\
\text { success in new and challenging } \\
\text { situations }\end{array}$ & Leader and subordinates go together & $\begin{array}{l}\text { Responsibility assignment for } \\
\text { performing tasks }\end{array}$ \\
\hline $\begin{array}{l}\text { Employees do not want to } \\
\text { perform a requested task }\end{array}$ & $\begin{array}{l}\text { Lead by example to improve } \\
\text { performance }\end{array}$ & $\begin{array}{l}\text { Decision making shared between } \\
\text { leader and followers }\end{array}$ & $\begin{array}{l}\text { Subordinates become independent } \\
\text { and confident }\end{array}$ \\
\hline $\begin{array}{l}\text { Emphasis is on task execution } \\
\text { and not in relationship }\end{array}$ & $\begin{array}{l}\text { Greater emphasis on the } \\
\text { relationship to ensure the task } \\
\text { execution }\end{array}$ & $\begin{array}{l}\text { Low emphasis on task versus high } \\
\text { emphasis on relationship }\end{array}$ & $\begin{array}{l}\text { Low emphasis on tasks as well as } \\
\text { in relationships }\end{array}$ \\
\hline $\begin{array}{l}\text { When to use: the team } \\
\text { consists of employees with } \\
\text { little maturity, experience and } \\
\text { knowledge }\end{array}$ & $\begin{array}{l}\text { When to use: the team is able to } \\
\text { take on challenges. The team is } \\
\text { mature, but have little knowledge } \\
\text { and experience }\end{array}$ & $\begin{array}{l}\text { When to use: the team consists of } \\
\text { experienced, competent employees, } \\
\text { however have gaps in responsibility, } \\
\text { motivation and insecurity }\end{array}$ & $\begin{array}{l}\text { When to use: the team is mature, } \\
\text { possesses experience and } \\
\text { knowledge of the status quo and } \\
\text { futurus. They like to be challenged }\end{array}$ \\
\hline
\end{tabular}

Source: Prepared by the authors from Hersey, Blanchard, and Johnson (2013). 
The variables that determine the effectiveness of each of these styles are intrinsically related to amplitude and level of maturity, commitment, experience and knowledge from the staff and especially the leader.

\subsection{Leaders X Managers}

Warren Bennis (1996) creator of the University Leadership Institute in Los Angeles (USA) based his leadership precepts on feelings or experiences, as well as on trust. Bennis (2001) points out that trust is vital on all levels of the organization, and its determinant is a security which he names "constancy". People opt to follow a leader they can trust, even if they disagree on numerous aspects.

According to this author, the nowadays leaders are instructor-like, require more commitment than submission, should be focused on their stakeholders, must possess some key characteristics that make them different from an administrator. The table 3 below summarizes the characteristics of a leader to Bennis (1996).

Table 3: Leader Types.

\begin{tabular}{|l|l|l|l|}
\hline \multicolumn{1}{|c|}{ Drive / Vision / Achiever } & \multicolumn{1}{|c|}{ Integrity } & Maturity \\
\hline $\begin{array}{l}\text { Clear and uniform idea of } \\
\text { what to do, regardless of } \\
\text { whether personal or } \\
\text { professional }\end{array}$ & Lider has to be ethical & $\begin{array}{l}\text { Leader know themselves, their } \\
\text { limitations courage and quality }\end{array}$ & Leader needs experience \\
\hline $\begin{array}{l}\text { Has the strength to persist } \\
\text { when facing difficulties }\end{array}$ & Ethics reinforces sincerity & $\begin{array}{l}\text { Take on challenges with the } \\
\text { knowledge that allows learning }\end{array}$ & $\begin{array}{l}\text { Need to have been led, to have } \\
\text { learned in obedience }\end{array}$ \\
\hline Denotes passion and ambition & $\begin{array}{l}\text { Strengthens the principles of } \\
\text { absolute integrity and character } \\
\text { uprightness }\end{array}$ & $\begin{array}{l}\text { Self-control even when facing } \\
\text { various intemperateness }\end{array}$ & $\begin{array}{l}\text { Other people's experiences are } \\
\text { aggregating }\end{array}$ \\
\hline $\begin{array}{l}\text { Knows where they want to } \\
\text { get }\end{array}$ & $\begin{array}{l}\text { Bases on the honesty of thoughts } \\
\text { and actions }\end{array}$ & $\begin{array}{l}\text { Knows they are able to go through } \\
\text { unfamiliar situations }\end{array}$ & $\begin{array}{l}\text { Not require servility, knows how } \\
\text { to listen and be empathetic }\end{array}$ \\
\hline
\end{tabular}

Source: Prepared by the authors from Bennis (2001)

One can notice that the maximum point for the leadership is the sum of these characteristics. Each one of them relates to the other, making the leader more effective as they are subjected to changes, innovations, courage, perseverance and others.

In this same approach, Shiyashiki cited in Resende (2008), points out that the leader must be in possession of some qualities, which are: Know the company's business; Innovate the present while creating the future; Turn threats into opportunities; Foster passion for results; Form teams that are integrated and committed; Courage, confidence, judgment, maturity and integrity. For him a leader cannot be a copy nor a commander. These characteristics are in line with the leading model designed by Bennis (2001), even in the comparative aspect Managers X Leaders. Oone of them is the approach that, while the manager administers, the leader innovates or as the manager maintains, the leader develops.

\subsection{The 4-Es of Leadership}

This was the last model created by Jack Welch, for before the vision of a 4-E leader, the author adopted different models and, in the same proportion to his research course the latest model would always be better adjusted set than the previous one.

Welch's central idea is the emphasis on the leader's role as agent of growth and professional development. Similar to Bennis (1996), Welch presents an innovative definition of Management. For him, "the fewer one manages, the better one manages," referring to delegating tasks and allocating challenges. The effective manager, in this case, delegates tasks but do 
not execute them, therefore the manager is seen as a leader as they act as such, since this is the mission of a leader, being a leader-manager and help their employees succeed.

According to Krames (2005), Welch's true leader seeks success through others, so one cannot reach a desired result on their own, but success is result of teamwork. For Welch, as reported by Krames (2005, p.2) "the world's smartest people are those who hire the smartest people " and complete emphasizing that Welch was looking for bright people.

In 1990, according to Krames (2005), the 4-E model emerges, "four kinds of business", in which Welch left the previous model, "head, heart and courage." This model was designed to help identify and develop leaders who fit the culture based on General Electric's performance and dynamism. Therefore, the characteristics shared by these leaders are: Energy; Energizer; Edge and; Execution. Figure 1 below demonstrates the four characteristics.

Figure 1: 4 Es Feature.

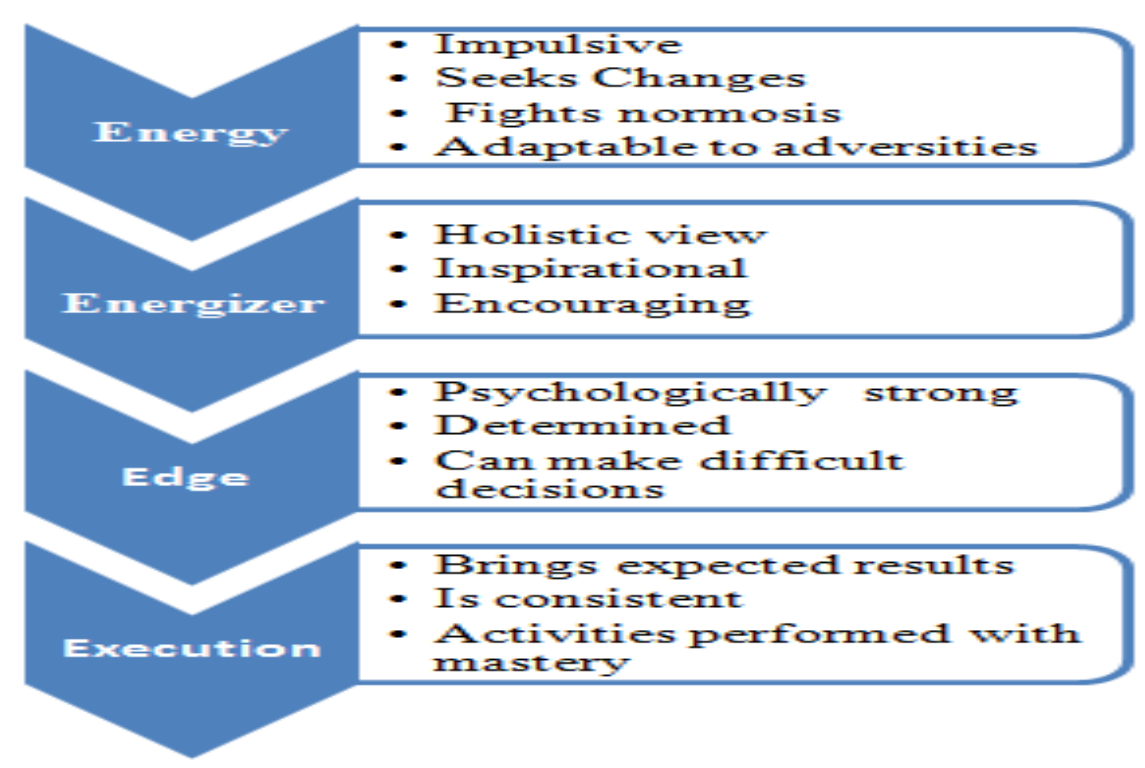

Source: Prepared by the author Krames (2005).

Welch's leader having the 4-Es, are connected to one another in a logical progression and are, at given times, between integrity and passion. The start of this flow is in Energy, pervading by Energizing as a source of effective leadership; Edge is the determination, strength, a leader of will, then finally Execution.

Similarly, to other authors studied here, Jack Welch describes the characteristics that should be of a 4-E leader. Next, Table 4 describes each of the characteristics. 
Table 4: Leader 4-Es.

\begin{tabular}{|c|c|c|c|c|c|}
\hline Strength & Competence & Vision & Client & Changes & Empathy \\
\hline $\begin{array}{l}\text { Knows how to lead with } \\
\text { character / integrity }\end{array}$ & $\begin{array}{l}\text { Expertise and insight to deal } \\
\text { with business }\end{array}$ & Holistic view & Focus in the chent & Avoids bureancracy & $\begin{array}{l}\text { Knows how to speak } \\
\text { and how to listen }\end{array}$ \\
\hline $\begin{array}{l}\text { Best leaders are the most } \\
\text { reliable }\end{array}$ & Instinct to deal with bosiness & Global mentality & $\begin{array}{l}\text { Understanding of Drucker } \\
\text { doctrine: a customer is able } \\
\text { to set the goal of a business }\end{array}$ & Changes are never ending & $\begin{array}{l}\text { They have "heart"; Are } \\
\text { not harsh }\end{array}$ \\
\hline Anthentic & Objective & Energy & Energizer & Goals & Execution \\
\hline Build effective teams & $\begin{array}{l}\text { Helps the company achieve } \\
\text { its goal }\end{array}$ & $\begin{array}{l}\text { Helps energize others to } \\
\text { generate results }\end{array}$ & Force multiplier & $\begin{array}{l}\text { Achieve goals and bring } \\
\text { results }\end{array}$ & Work happly \\
\hline Surpass goals & $\begin{array}{l}\text { Individual contributions are } \\
\text { to be aggregated to the } \\
\text { company / willingly help the }\end{array}$ & $\begin{array}{l}\text { Articulate a vision and lead } \\
\text { others to adopt it }\end{array}$ & Is contagious & $\begin{array}{l}\text { Exceed financial } \\
\text { expectations }\end{array}$ & Lowe what they do \\
\hline
\end{tabular}

Source: Prepared by the authors from Krames (2005).

It must be noted that the characteristics appointed to the leaders by these authors have relevant points of intersection.

\section{Research Methodology}

This is a basic, qualitative research, of exploratory nature and descriptive character, as it observes, analyses and interprets facts (Beuren and Raupp 2003).

As for the procedure, this research was analytical in line with Marconi and Lakatos' (2009) understanding, covering the literature in the public domain regarding the issue at hand, such as books, articles, dissertations, etc.

Information on the bibliography analyzed was classified according to interpretive epistemological approach. Data were capitulated through reflective reading on the subject, then the authors were classified detailing their approach on leadership styles. Finally, it was established a parallel (comparative) among different authors, and therefore the identification of appropriate aspects among the characteristics addressed by them.

\section{Presentation and Analysis}

By establishing a parallel between the leadership styles proposed by Blanchard and Hersey; Bennis (1996) and Welch taking as a central idea Max Weber's (2016) leadership and Formal Authority, we must consider that several aspects are congruent, and others are asymmetric to each other.

Leader's temporal effectiveness that makes them employ different styles in different situations, which assimilates the situational theory proposed by Hersey, Blanchard, and Johnson (2013), may be associated to positive Energy proposed as a characteristic of Jack Welch's leader. Bennis's (1996) self-control can be considered as intersect point as well as the strength to persist when facing difficulties and new situations.

Guiding others to achieve the desired result in new, atypical and challenging situations, is the style of Hersey, Blanchard and Johnson's (2013) leader, then the team is ready to take challenges, since there has been a coaching job, given the team's limited experience. Welch works with this same perception when he relates the Energy; the ability to Energize in order to add value, can also be associated with the trait of empathy, which is a feature highlighted by Bennis (1996) in "maturity". Bennis's (1996) leader does not require servility, it is empathic.

It was observed during the contextualization of this research the emphasis given to Jack Welch in the leader's role as an agent of growth and professional development. Bennis (1996) and Welch have an innovative definition of the term 
Management, however when examining Hersey, Blanchard, and Johnson's (2013) Command category, one sees an antagonistic bias, however when analysing the Delegation category, the leader is on breakeven point compared to the other authors.

However, If to Bennis (1996) the analysis of Leadership performance occurs through "facilitating and promoting attitudes," his effective leader is one who allows and accepts new ideas that propose changes. Jack Welck's leader, established in the 4-E theory, is one "without limits", which depicts an individual without holds, who recognize their business and defining changes. On the other hand, one must challenge, although tenuously, Hersey, Blanchard, and Johnson (2013) leader in relation to Welch and Bennis (1996).

Hersey, Blanchard and Johnson 's (2013) leader can be a facilitator and promoter, as they are adaptable to situations, however, if the approach is literal, it cannot be considered "without limits". It is important not to association the leader to unconvincingly mimicry, since instead of denoting openness, break of paradigm, this leader can be considered as one "boss" or "administrator" "withount personality" or "inauthentic" therefore opposed to the basic concept of Leader.

The Weberian power, not in its essence, was not identified eloquently in the works developed by these authors. The bureaucracy in Max Weber's (2016) rational-legal described as essential to organization was opposed by Jack Welch. The latter believes that the organization of a company not necessarily permeates the bureaucracy that only slows down the process. On the other hand, the Werberian bureaucracy is not present on a daily basis in the ordinary census, especially that from the government agencies.

A common denominator identified in all the authors and therefore their Leadership theories refer to Integrity, which comes to the uprightness of character, ethics and above all respect for the individual.

In the research by Silva, Paschoalotto and Endo (2020) about organizational leadership within the aspect of an integrative Brazilian review, the intersection between ethics and leadership is noted. Bedi; Alpaslan \& Green (2016 apud Silva, Paschoalotto and Endo, 2020, p. 3) emphasize that ethics is related to leadership and the posture that is conveyed by leadership can be an influencing aspect in the representation of those led, being positively related to perception of justice and the ethical behavior of the individual employee.

\section{Conclusion}

Contemporaneously, organizations are concerned to broaden the perception and consciousness through their vision and understanding of business, leaders, administrators, managers, bosses on the leadership role in the face of today's situation that makes them faster, more complex and competitive. In this perspective, the development, specifically of leaders and leadership, has received a prominent role in organizations, which during the past century have favoured management.

As noted during this study, the dynamic leadership styles proposed by the authors has as the pressing challenge the wisdom to capture and improve their leaders' performance or transform their employees into successful leaders, following the precepts Authority; Integrity; Maturity; Energy; Self-knowledge and others. However, at the same amplitude in which the equivalent characteristics between the leaders of many styles are evident, there are those who flock to an ambiguous interpretation, as in the case of Autocracy, although the "command" mode can be understood as centralization, tyranny, despotism, attitudes not associated to successful leaders by most authors studied in this research and not appropriate in the current organizational environment, even for situational questions.

One has to conclude that operational compliance process does not counterbalance ineffective people; however, operational compliance process does not block effective people. In this antagonism, the employee ceases to be "simply a piece of Taylor," and goes on to add value once they have the authority over entire system. The combination between effective leaders and operational compliance process is value-adding for the maintenance and growth of organizations. 
It is suggested for futures researches the application of dark triad concepts for management and leadership assessments, mainly to consider the challenges, limitations and the difficulty of capturing and leading new potentials in a new context brought by the Coronavirus pandemic.

\section{References}

Bedi, A., Alpaslan, C. M., \& Green, S. (2015). A Meta-analytic Review of Ethical Leadership Outcomes and Moderators. Journal of Business Ethics, 139(3), 517-536,

Bennis, W. (1996). A formação do líder. Atlas.

Bennis, W. (2001). A nova liderança. In: Coletânea HSM Management. Liderança e gestão de pessoas: autores e conceitos imprescindíveis. PUBLIFOLHA.

Beuren, Ilse M. \& Raupp, Fabiano M. (2003). Metodologia da pesquisa aplicada às ciências sociais. Atlas.

Conley, S., \& You, S. (2018). School organizational factors relating to teachers' intentions to leave: A mediator model. Current Psychology, 1-11.

Chowdhury, S. (2020). The `4v`approach in strategic human resource management post-COVID-19. International Journal of Engineeringand Management Research, 10(4),.98-105.

Druker, P. (2016). Inovação e espírito empreendedor: prática e princípios. Cengage Learning

Encyclopedia Mirador Internacional. (1991). Britannica do Brasil.

Hersey, P., Blanchard, K., \& Johnson D. (2013), Management of Organizational Behavior: leading Human Resources. Ed., Prentice-Hall of India Pvt.Ltd.

Johannpeter, A. (2008). O novo líder tem que ser global. Revista Você S/A. 123, 139.

Kotter, J. P. (1997). Liderando Mudanças. Campus/Elsevier.

Krames, J. (2005). O estilo Jack Welch de Liderança. Campus/Elsevier.

Marconi, A., \& Lakatos, M. (2009). Fundamentos da Metodologia Científica. (6a ed.), Atlas

Moscovici, F. (2006). Renascença Organizacional. (8a Ed). Jose Olympio

Mueller, A \& Mayer, L. (2003). Liderança: novos conceitos diante de uma nova realidade - VI SEMEAD - Ensaios Recursos Humanos / FEA -USP.

Resende, E. (2004). A força e o poder das competências, conecta e integra, Qualytmark,

Resende, V. (2008). Como identificar um verdadeiro Líder.? Revista FENACON, ano XIII, 18 -19

Rhinesmith, S. (2003). Guia gerencial para globalização.

Robbins, S., Judge Timothy A. \& Sobral, Filipe. (2010). O comportamento organizacional: teoria e pratica no contexto organizacional brasileiro. Pearson Prentice Hall.

Ronchi, C. (2007). O processo da Liderança - conceitos, tipos e aplicações. Editora GdN.

Senge, Peter. (2009). A Quinta Disciplina: caderno de campo - estratégias e ferramentas para construir uma organização que aprende. Qualitymark.

Silva, Caio P., Paschoalotto, Marco A. C. \& Endo, G. Y. (2020) Liderança Organizacional: Uma Revisão Integrativa Brasileira. Revista Pensamento Contemporâneo em Administração. 14(1), 1982-2596. https://doi.org/10.12712/rpca.v14i1.36370

Vergara, S. (2014). Gestão de Pessoas. Atlas.

Weber, M. (2016). Metodologia das ciências sociais. (5a ed.), Cortez.

Werneck, T. S. (2020). Novos Desafios no Gerenciamento dos Recursos Humanos frente a pandemia da Covid-19. Boletim do Gerenciamento, 17(17), 1-9. 